\title{
Perbedaan Persiapan Siswa yang Hasil Belajar Tinggi dan Rendah dalam Menghadapi Ujian Nasional
}

\author{
Linda Fitria $^{1}$
}

${ }^{1}$ Fakultas Ilmu Pendidikan, Universitas Negeri Padang

\begin{abstract}
To pass the examination, the most important thing to be considered by the students is the examination preparation. There are so many kinds of examination faced by the students, one of it is national examination. Therefore, the national examination should be prepared well by the students, school, and parents since it is a tool to measure students competency of achievement which held by education unit in order to obtain learning confession and it is a requirement of finishing education level. This research is aimed to describe and differentiate the preparation of students with high learning achievement and the students with low learning achievement in facing national examination. This is a comparative quantitative descriptive approach supported with interview. The target of the research is students of SMA Adabiah Padang of academic year 2012/2013, with 327 students as the population. There are 80 students placed as sample. The research finding reveals that (1) physical preparation of students with high learning achievement and the students with low learning achievement in facing national examination is in well prepared category (2) psychology preparation for both students with high learning achievement and the students with low learning achievement is in well prepared category, (3) the preparation in mastering the learning material for both students with high learning achievement and the students with low learning achievement is in well prepared category,(4) the analysis of t test result reveals that there is a significant difference between students with high learning achievement and the students with low learning achievement of SMA Adabiah Padang
\end{abstract}

Keyword: Preparation National Examination, Students Learning Achievement

Copyright (C) 2013 IICE - Multikarya Kons (Padang - Indonesia) dan IKI - Ikatan Konselor Indonesia - All Rights Reserved Indonesian Institute for Counseling and Education (IICE) Multikarya Kons

\section{PENDAHULUAN}

Pendidikan nasional harus mampu menjamin pemerataan kesempatan pendidikan, peningkatan mutu dan relevansi serta efisiensi manajemen pendidikan. Ditinjau dari segi fungsi Pendidikan Nasional yang telah dijelaskan dalam Undang-undang Sistem Pendidikan Nasional No. 20 tahun 2003 pasal 3 menyatakan bahwa:

Pendidikan nasional berfungsi mengembangkan kemampuan dan membentuk watak serta peradaban bangsa yang bermartabat dalam rangka mencerdaskan kehidupan bangsa, bertujuan untuk berkembangnya potensi peserta didik agar menjadi manusia yang beriman dan bertakwa kepada

\footnotetext{
* Telp atau Alamat Email Koresponden :

${ }^{1}$ E-mail address: lindafitria@yahoo.com
} 
Tuhan Yang Maha Esa, berakhlak mulia, sehat, berilmu, cakap, kreatif, mandiri, dan menjadi warga negara yang demokratis serta bertanggung jawab.

Berdasarkan kutipan di atas dapat dikemukakan bahwa upaya pengembangan manusia dapat dilakukan melalui pendidikan. Sekolah Menengah Atas (SMA) merupakan salah satu bentuk satuan pendidikan yang menyelenggarakan pendidikan tiga tahun setelah pendidikan wajib belajar sembilan tahun.

Untuk dapat menyelesaikan satu tingkat satuan pendidikan dan untuk melanjutkan pendidikan kejenjang yang lebih tinggi siswa harus harus lulus ujian. Selain ujian semester dan ulangan harian yang harus dilewati oleh siswa, ada lagi ujian yang mesti diikuti oleh siswa pada akhir pendidikannya yaitu Ujian Nasional. Ujian Nasional tingkat SMA merupakan penentu seorang siswa untuk dapat melanjutkan pendidikan keperguruan tinggi. Untuk tahun 2012, pemerintah pusat telah menetapkan standar kelulusan yaitu 5,5.

Adapun standar kelulusan diatur dalam Peraturan Pemerintah No.19 Tahun 2005 tentang Standar Nasional Pendidikan pasal 72 ayat 1 yang menyatakan bahwa:

Peserta didik akan dinyatakan lulus dari satuan pendidikan memenuhi tiga syarat lain yaitu menyelesaikan seluruh pembelajaran, memperoleh nilai baik pada penilaian akhir untuk seluruh mata pelajaran, kelompok mata pelajaran agama dan akhlak mulia, kelompok mata pelajaran kewarganegaraan, kepribadian, kelompok mata pelajaran estetika, dan kelompok mata pelajaran jasmani, olah raga, dan kesehatan, dan lulus ujian sekolah/madrasah untuk kelompok mata pelajaran ilmu pengetahuan dan teknologi.

Berdasarkan peraturan di atas, beberapa hal yang seharusnya dimiliki oleh semua siswa adalah harus dapat mencapai nilai yang cukup sesuai dengan standar yang sudah ditetapkan oleh Badan Standar Nasional Pendidikan (BSNP).

Untuk dapat lulus dalam mengikuti ujian tersebut hal yang paling penting diketahui siswa adalah persiapan menghadapi ujian. Oleh karena itu persiapan dalam menghadapi ujian nasional hendaknya dilakukan sebaik mungkin oleh sekolah, guru, siswa, maupun orang tua, karena ujian nasional merupakan kegiatan pengukuran pencapaian kompetensi siswa yang dilakukan pada setiap satuan pendidikan untuk memperoleh pengakuan atas prestasi belajar dan merupakan syarat siswa untuk menyelesaikan tingkat satuan pendidikan tersebut.

Menurut Irawadiy (2009:01) Persiapan adalah suatu kegiatan yang akan dipersiapkan sebelum melakukan sebuah kegiatan. Tanpa persiapan, kegiatan tidak akan terlaksanakan dengan baik ataupun susah untuk dilaksanakan. Sebaliknya jika persiapan dilakukan dengan sebaik mungkin, maka kegiatan itu akan terlaksana dengan baik. Hasil dari persiapan adalah sebuah kegiatan yang memuaskan.

Sedangkan Tarmizi (2009:01) menyatakan bahwa persiapan dalam menghadapi ujian nasional ini dimulai dari persiapan diri, persiapan teknis, persiapan materi ujian, dan pada saat ujian. Persiapan diri adalah persiapan yang dimulai dari dalam diri sendiri, yang meliputi persiapan fisik dan persiapan mental. Persiapan fisik berkaitan dengan persiapan jasmani/fisik dan persiapan kesehatan.

Dari definisi di atas, dapat disimpulkan bahwa yang dimaksud dengan persiapan adalah segala sesuatu kegiatan atau perbuatan yang dilakukan oleh siswa, sebelum siswa tersebut melaksanakan UN yang meliputi persiapan fisik, psikis dan persiapan penguasaan materi ujian.

Secara umum penelitian ini bertujuan untuk mendeskripsikan perbedaan persiapan siswa yang hasil belajar tinggi dan rendah dalam menghadapi ujian nasional.

\section{METODOLOGI}

Penelitian ini merupakan Penelitian ini merupakan penelitian dengan menggunakan metode deskriptif dengan pendekatan kuantitatif, dan Jenis penelitian yang akan digunakan adalah penelitian deskriptif komparatif dan didukung dengan data hasil wawancara.

Penelitian ini akan mendeskripsikan Penelitian ini akan mengungkap dan mendeskripsikan perbedaan persiapan siswa menghadapi ujian nasional antara yang hasil belajar tinggi dan rendah di SMA Adabiah 2 Padang. Adapun populasi dalam penelitian ini adalah siswa kelas XII SMA Adabiah 2 Padang yang terdaftar pada tahun ajaran 2012/2013 yang berjumlah 327 orang. Untuk menentukan jumlah sampel diambil dari lima orang yang hasil belajarnya tinggi dan lima orang yang hasil belajar rendah, maka sampel penelitian adalah sebanyak 80 orang. 
Adapun teknik pengumpulan datanya dilakukan melalui pengadministrasian instrumen berupa koesioner/angket kepada sampel penelitian dan wawancara dengan siswa, orangtua siswa, guru bimbingan dan konseling (BK) dan wali kelas. Data yang telah terkumpul dianalisis dengan cara mendeskripsi data tentang persiapan siswa menghadapi ujian nasional dianalisis dengan menggunakan rumus persentase Menurut A. Muri Yusuf (2005:259).

Penetapan kriteria menentukan klasifikasi/pengkategorian persiapan siswa, peneliti menggunakan dasar pengklasifikasian menurut Soegyarto (1997:17).

Pengujian perbedaan persiapan belajar siswa antara yang hasil belajar tinggi dan hasil belajar rendah maka digunakan uji $\mathrm{t}$ atau $\mathrm{t}$ test, untuk menguji signifikansi perbedaan dua buah mean yang berasal dari dua buah distribusi. Menurut Winarno (2002:87).

\section{HASIL DAN PEMBAHASAN}

Hasil analisis dapat dilihat pada tabel berikut:

Tabel 1.

Persiapan Fisik $(n=40)$

\begin{tabular}{ccccc}
\hline Kategori & \multicolumn{2}{c}{ Hasil Belajar Tinggi } & \multicolumn{2}{c}{ Hasil Belajar Rendah } \\
\cline { 2 - 5 } & Frek-wensi & Persentase & Frek-wensi & Persentase \\
Sangat Siap (SS) & 12 & 30 & 10 & 25 \\
Siap (S) & 17 & 42,5 & 12 & 30 \\
Kurang Siap (KS) & 7 & 17,5 & 14 & 35 \\
Tidak Siap (TS) & 4 & 10 & 4 & 10 \\
\hline
\end{tabular}

Berdasarkan tabel $1 \mathrm{di}$ atas hasil analisis data menunjukkan bahwa siswa yang hasil belajarnya tinggi lebih siap dalam menghadapi ujian nasional dilihat dari segi fisik.

Tabel 2.

Persiapan Psikis

\begin{tabular}{ccccc}
\hline Kategori & \multicolumn{2}{c}{ Hasil Belajar Tinggi } & \multicolumn{2}{c}{ Hasil Belajar Rendah } \\
\cline { 2 - 5 } & Frek-wensi & Persentase & Frek-wensi & Persentase \\
Sangat Siap (SS) & 15 & 37,5 & 7 & 17,5 \\
Siap (S) & 24 & 60 & 14 & 35 \\
Kurang Siap (KS) & 0 & 0 & 18 & 45 \\
Tidak Siap (TS) & 1 & 2,5 & 1 & 2,5 \\
\hline
\end{tabular}

Berdasarkan tabel 2 di atas hasil analisis data menunjukkan bahwa siswa yang hasil belajarnya tinggi lebih siap dalam menghadapi ujian nasional dilihat dari segi psikis.

Tabel 3.

Persiapan Menguasai Materi Pelajaran

Kategori Hasil Belajar Tinggi

Hasil Belajar Rendah

\begin{tabular}{|c|c|c|c|c|}
\hline & & \\
\hline & Frek-wensi & Persentase & Frek-wensi & Persentase \\
\hline Sangat Siap (SS) & 7 & 17,5 & 6 & 15 \\
\hline Siap $(\mathrm{S})$ & 14 & 35 & 27 & 67,5 \\
\hline Kurang Siap (KS) & 6 & 15 & 18 & 45 \\
\hline Tidak Siap (TS) & 1 & 2,5 & 1 & 2,5 \\
\hline
\end{tabular}

Berdasarkan tabel 3 di atas hasil analisis data menunjukkan bahwa siswa yang hasil belajarnya tinggi lebih siap dalam menghadapi ujian nasional dilihat dari segi persiapan menguasai materi pelajaran.

Pengujian hipotesis dilakukan dengan menggunakan teknik analisa data $t$ tes. Uji hipotesis dilakukan setelah persyaratan analisis data terpenuhi. Hasil pengujian analisis terhadap data menunjukkan bahwa distribusi frekuensi data yang diuji adalah normal dan homogen. Adapun hipotesis yang dikemukakan pada penelitian ini yaitu "Terdapat Perbedaan Persiapan Siswa Hasil Belajar Tinggi dan Terendah dalam Menghadapi Ujian Nasional".

Selanjutnya data yang diperoleh diuji dengan menggunakan program statistik SPSS (Statistical Product and Service Solution) for Window Release 18.00. Hasil pengujian hipotesis tersebut adalah sebagai berikut: 
Tabel 4.

Perbedaan Persiapan Siswa yang Hasil Belajar Tinggi dan Rendah dalam Menghadapi Ujian Nasional di SMA Adabiah 2 Padang

\begin{tabular}{|c|c|c|c|c|c|c|}
\hline Perbedaan persiapan & & $\mathrm{F}$ & Sig. & $\mathrm{t}$ & Df & $\begin{array}{l}\text { Sig. }(2- \\
\text { tailed) }\end{array}$ \\
\hline $\begin{array}{l}\text { siswa yang hasil belajar } \\
\text { tinggi dan rendah }\end{array}$ & $\begin{array}{l}\text { Equal variances } \\
\text { assumed }\end{array}$ & 0,716 & 0,400 & 8,066 & 78 & 0,000 \\
\hline $\begin{array}{l}\text { dalam menghadapi } \\
\text { ujian nasional }\end{array}$ & $\begin{array}{l}\text { Equal variances not } \\
\text { assumed }\end{array}$ & & & 8,066 & 77,987 & 0,000 \\
\hline
\end{tabular}

Pada tabel 4 di atas dapat dilihat nilai $\mathrm{F}$ yang diperoleh dari data penelitian adalah 0,716 dengan signifikansi 0.400 (besar dari 0.05), maka nilai t yang dipakai adalah equal variance assumed atau diasumsikan kedua varian adalah sama. Nilai t yang diperoleh 8,066 dengan probabilitas 0.000 ,

Secara lebih rinci, hasil analisis data dengan melihat nilai t, maka diperoleh nilai t 8,066 dengan derajat kebebasan (df) 78. Nilai t tabel signifikan 5\% adalah 2,021. Karena nilai t yang diperoleh adalah 8,066 sedangkan nilai t tabel adalah 2,021 maka nilai thitung lebih besar dari t tabel pada taraf signifikan 5\%, dengan demikian terdapat perbedaan yang signifikan. Sehingga diperoleh kesimpulan bahwa terdapat perbedaan yang signifikan antara persiapan siswa yang hasil belajar tinggi dan rendah dalam menghadapi ujian nasional di SMA Adabiah 2 Padang.

\section{PEMBAHASAN}

Berdasarkan hasil pengujian yang telah dilakukan dapat dibuktikan bahwa terdapat perbedaan yang signifikan antara persiapan siswa yang hasil belajar tinggi dan rendah dalam menghadapi ujian nasional. Pada bagian berikut dijelaskan pembahasan untuk masing-masing variabel yang dikaji dalam penelitian ini.

\section{Persiapan Fisik Siswa yang Hasil Belajar Tinggi dan Rendah dalam Meghadapi Ujian Nasional}

Berdasarkan temuan penelitian berkaitan dengan persiapan fisik dapat diketahui bahwa persiapan fisik siswa yang hasil belajar tinggi dalam menghadapi UN secara umum dalam kategori siap (72,5\%). Dan persiapan fisik untuk siswa yang hasil belajar rendah dalam menghadapi UN secara umum juga dalam kategori siap (55\%).

Dari hasil penelitian ini diketahui bahwa siswa memiliki persiapan yang cukup baik dalam persiapan fisik, baik dalam menjaga kesehatan tubuh maupun kondisi fisiknya. Sehingga membuat mereka siap menghadapi ujian, karena kondisi fisik yang terganggu dapat mengganggu aktivitas sehari-hari, termasuk dalam mengikuti ujian nasional. Hal ini sesuai dengan pendapat yang dikemukakan oleh Kartini Kartono (1983: 35), bahwa jika kesehatan fisik seseorang terganggu atau tidak sehat, lelah atau mengantuk pada saat mengerjakan ujian maka siswa tersebut tidak akan dapat mengerjakan ujian dengan baik.

Selain itu Dewa Ketut Sukardi (1983:41) juga mengemukakan bahwa tanpa kondisi fisik yang optimal atau sehat, maka secara langsung akan berpengaruh terhadap proses berpikir. Kondisi fisik yang tidak optimal akan mempengaruhi proses berpikir. Untuk itu perlu dilakukan berbagai upaya agar hal ini dapat segera diatasi seperti menjaga kesehatan tubuh dengan selalu berolahraga, makan-makanan yang bergizi, istirahat yang cukup, minum susu serta mengurangi kegiatan yang melelahkan.

Berdasarkan hasil penelitian di atas yang perlu diperhatikan adalah bagaimana untuk memotivasi siswa agar selalu menjaga kondisi fisiknya sehingga mereka selalu siap dalam menghadapi kondisi apapun, baik untuk belajar ataupun menghadapi ujian.

2. Persiapan Psikis Siswa yang Hasil Belajar Tinggi dan Hasil Belajar Rendah dalam Meghadapi Ujian Nasional

Berdasarkan temuan penelitian berkaitan dengan persiapan psikis dapat diketahui bahwa persiapan psikis siswa yang hasil belajar tinggi dalam menghadapi UN secara umum dalam kategori siap (97,5\%). Dan persiapan psikis untuk siswa yang hasil belajar rendah dalam menghadapi UN secara umum juga dalam kategori siap $(52,5 \%)$.

Dalam hal persiapan psikis siswa dalam menghadapi ujian dalam kategori siap untuk siswa yang hasil belajar tinggi, dan ini menyatakan bahwa siswa cukup siap secara psikis dalam menghadapi ujian nasional. Sesuai dengan pendapat Thursan (2002:12) yang menyatakan bahwa faktor psikis sangat mempengaruhi keberhasilan belajar. Kondisi mental yang dapat menunjang keberhasilan belajar adalah kondisi mental 
yang mantap dan stabil seperti persiapan psikis siswa dalam membangkitkan minat dan perhatian, meningkatkan motivasi, konsentrasi, menenangkan emosi.

Selain itu yang perlu diperhatikan oleh orang tua adalah masih ada siswa yang tidak mengulang pelajaran yang telah dipelajari di sekolah di rumah, tidak mengatur jadwal belajar dengan baik serta tidak belajar secara rutin. Orang tua harus bisa mengatur waktu belajar anak di rumah seperti yang dikemukakan oleh M. Sobri (2007:18) bahwa orang tua harus memahami waktu-waktu dalam belajar anaknya sehingga tidak tumpang tindih antara waktu belajar dengan waktu untuk bermain.

Berdasarkan hasil penelitian di atas yang perlu diperhatikan lagi adalah untuk siswa yang hasil belajar rendah perlu motivasi dan dorongan yang lebih dari berbagai pihak terutama orangtua, guru BK dan orangorang terdekat lainnya sehingga siswa lebih siap lagi secara psikis dalam menghadapi UN.

3. Persiapan Siswa yang Mempunyai Hasil Belajar Tinggi dan Rendah dalam Menguasai Materi yang Akan Diujikan dalam Ujian Nasional

Berdasarkan temuan penelitian berkaitan dengan persiapan menguasai materi yang akan diujikan dalam ujian nasional dapat diketahui bahwa persiapan menguasai materi yang akan diujikan, siswa yang hasil belajar tinggi dalam menghadapi UN secara umum dalam kategori siap (82,5\%). Dan persiapan menguasai materi yang akan diujikan untuk siswa yang hasil belajar rendah dalam menghadapi UN secara umum dalam kategori siap (52,5\%).

Dalam hal persiapan menguasai materi yang akan diujikan dalam ujian nasional sudah dalam kategori baik, dan ini menyatakan bahwa siswa sudah siap secara penguasaan materi yang akan diujikan dalam ujian nasional. Keberhasilan seorang siswa dalam belajar sangat dipengaruhi oleh cara belajarnya. Siswa yang mempunyai strategi belajar yang baik akan lebih memungkinkan untuk mencapai prestasi yang lebih tinggi, demikian dengan sebaliknya. (Kartini Kartono, 1985: 24).

Hal ini juga sesuai dengan yang dikemukakan oleh Hasbullah (1995: 113-119) mengemukakan bahwa adapun bentuk persiapan yang dilakukan siswa untuk menguasai materi adalah :

a. Mengatur jadwal untuk mengulang materi pelajaran yang akan diujikan dalam ujian dan mentaatinya.

b. Melengkapi catatan yang kurang lengkap.

c. Mempelajari tugas-tugas yang telah dikerjakan setelah memperbaikinya.

d. Membuat ringkasan dari bahan bacaan dalam bentuk bagan atau grafik.

e. Membahas soal-soal ujian pada tahun lalu dengan teman/guru sehingga siswa memiliki gambaran tentang soal-soal yang akan diujikan dalam ujian.

Abu dkk (2003:34) juga menjelaskan bahwa ada dua persyaratan utama untuk dapat menguasai materi pelajaran dengan baik, yaitu adanya perhatian khusus dan motivasi yang kuat. Kedua hal tersebut harus dimiliki siswa sehingga siswa tetap bersemangat dalam belajar dan tidak ada bagian dari materi pelajarannya yang tertinggal.

Meskipun begitu dalam hal persiapan menghadapi materi ujian secara keseluruhan siswa telah mempersiapkan segalanya dengan baik. Berkenaan dengan temuan hasil penelitian di atas maka perhatian dari guru dan personil sekolah khususnya guru BK sangat diperlukan dalam rangka mempersiapkan siswa menghadapi ujian agar mencapai hasil yang maksimal.

Dalam hal ini guru BK diharapkan melaksanakan layanan bimbingan konseling misalnya layanan penguasaan konten seperti yang dikemukakan oleh Prayitno, dkk (1994: 24) sebagai berikut:

a. Pengenalan siswa yang mengalami masalah belajar tentang kemampuan, motivasi, sikap dan kebiasaan belajar.

b. Pengembangan motivasi, sikap dan kebiasaan belajar yang baik.

c. Pengembangan keterampilan belajar seperti membaca, mencatat, bertanya dan menjawab.

Salah satu bantuan yang dapat dilakukan adalah melalui layanan penguasaan konten. Hal ini dapat ditempuh guru BK dengan cara menumbuhkan, mengaktifkan dan membina kelompok-kelompok belajar serta memberikan materi layanan penguasaan konten dan informasi yang ada khususnya materi yang berkaitan dengan persiapan siswa menghadapi UN.

Selain itu guru BK di sekolah juga mengadakan layanan bimbingan kelompok. Dengan adanya kegiatan bimbingan kelompok siswa dapat membahas, memasukkan saran, ide, atau solusi untuk memecahkan masalah-masalah yang berkaitan dengan persiapan siswa dalam menghadapi ujian. 


\section{Perbedaan Persiapan Siswa yang Hasil Belajar Tinggi dan Rendah dalam Meghadapi Ujian Nasional}

Hasil temuan penelitian mengungkapkan bahwa terdapat perbedaan yang signifikan antara persiapan siswa yang hasil belajar tinggi dan rendah dalam meghadapi ujian nasional.

Perbedaan ini dapat dilihat dari sub variabel persiapan siswa menghadapi ujian nasional antara siswa yang hasil belajar tinggi dan rendah, persentase yang cenderung tinggi ditempati siswa yang hasil belajar tinggi. Persiapan seorang siswa dianggap baik apabila ia memiliki persiapan fisik, psikis ataupun persiapan menguasai materi pelajaran yang baik pula.

Perbedaan ini disebabkan oleh beberapa faktor seperti persiapan fisik, yaitu bagaimana siswa itu menjaga kondisi fisiknya agar tetap sehat dan bugar, yang dapat mempengaruhi keadaannya pada saat ujian nantinya. Begitu juga dalam mempersiapkan mental dan psikis, terdapat perbedaan antara siswa yang hasil belajarnya tinggi dengan siswa yang hasil belajar rendah.

Dalam menguasai materi pelajaranpun terdapat perbedaan antara siswa yang hasil belajar tinggi dan rendah. Menurut Syaiful (2000:127-129) mengemukakan bahwa kualitas penguasaan materi pelajaran dapat meningkatkan keyakinan pada diri sendiri saat mengerjakan/menjawap pertanyaan dalam ujian.

Agar penguasaan materi pelajaran itu dapat dikuasai dengan baik, hal yang perlu diperhatikan adalah:

a. Siswa harus mengetahui apa yang dihasilkan dalam belajar,

b. Siswa memahami apa yang dilakukan untuk dapat sukses dalam belajar,

c. Siswa memahami kegiatan belajar untuk mencapai sukses dalam belajar.

d. Siswa harus menghindari perbuatan yang berlebihan sehingga mengabaikan kegiatan belajar,

e. Buktikan kemampuan siswa dengan fakta yang dapat menjelaskan berbagai sudut pandang yang berbeda melalui berbagai jenis ujian,

f. Nyatakan keinginan dan maksud siswa dengan nada yang meyakinkan tanpa menunjukan keraguan dalam menghadapi ujian nasional (Mungin, 2011:6)

Berdasarkan paparan di atas jelaslah bahwa perbedaan persiapan siswa yang hasil belajar tinggi dan rendah berbeda. Perbedaan tersebut dapat dilihat dari sub variabel pada persiapan fisik, psikis dan menguasai materi pelajaran.

\section{SIMPULAN DAN SARAN}

Berdasarkan temuan dan pembahasan hasil penelitian, maka dapat dikemukakan kesimpulan-kesimpulan sebagai berikut:

1. Persiapan siswa di SMA Adabiah Padang berdasarkan temuan penelitian berkaitan dengan persiapan fisik siswa yang hasil belajar tinggi dalam menghadapi UN secara umum berada pada kategori siap. Dan persiapan fisik untuk siswa yang hasil belajar rendah dalam menghadapi UN secara umum juga dalam kategori siap.

2. Persiapan siswa di SMA Adabiah Padang berdasarkan temuan penelitian berkaitan dengan persiapan psikis siswa yang hasil belajar tinggi dalam menghadapi UN secara umum dalam kategori siap. Dan persiapan fisik untuk siswa yang hasil belajar rendah dalam menghadapi UN secara umum juga dalam kategori siap.

3. Persiapan menguasai materi pelajaran yang akan diujikan dalam UN, siswa yang hasil belajar tinggi secara umum dalam kategori siap. Dan persiapan menguasai materi yang akan diujikan dalam UN, siswa yang hasil belajar rendah secara umum dalam kategori siap.

4. Terdapat perbedaan yang signifikan antara persiapan siswa yang hasil belajar tinggi dan rendah dalam menghadapi ujian nasional di SMA Adabiah 2 Padang. Hal ini berarti siswa yang hasil belajar tinggi memiliki persiapan yang lebih baik dibandingkan dengan persiapan siswa yang hasil belajar rendah.

Hasil penelitian yang dilakukan mengenai persiapan siswa yang hasil belajar tinggi dan rendah sebagaimana dikemukakan pada Bab IV berada pada kategori siap dan masih ada yang berada pada kategori kurang siap bahkan tidak siap dalam menghadapi ujian nasional. Untuk menciptakan kondisi siap ataupun sangat siap dalam menghadapi ujian nacional maka perlu diberikan pelayanan bimbingan dan konseling khusus untuk mempersiapkan siswa menghadapi ujian nasional, sekaligus untuk pengembangan dan pencapaian pendidikan serta hasil ujian yang maksimal. Khusus untuk persiapan siswa yang hasil belajar rendah pada masing-masing variabel berada pada kategori kurang siap, temuan ini mengindikasikan diperlukannya program yang dapat mempersiapkan siswa menghadapi ujian nasioal. 
Berdasarkan hasil penelitian tersebut untuk mempersiapkan siswa menghadapi ujian nasional maka guru BK dapat melakukan hal-hal sebagai berikut:

1. Guru BK diharapkan mampu menyajikan materi-materi yang bertujuan untuk memepersiapkan siswa menghadapi ujian nasional seperti persiapan fisik, psikis melalui layanan BK dengan format klasikal seperti layanan informasi dan layanan penguasaan konten dengan metode yang menarik, dan bervariasi serta lebih mudah untuk dipahami siswa.

2. Guru BK diharapkan memiliki wawasan yang luas tentang bagaimana mempersiapkan siswa menghadapi ujian nasional.

3. Guru BK memberikan berbagai layanan yang dibutuhkan siswa.

4. Guru BK hendaknya menjalin kerjasama dengan guru mata pelajaran, wali kelas dan orangtua untuk mempersiapkan siswa menghadapi ujian nasional.

Berdasarkan hasil penelitian, pembahasan hasil penelitian, kesimpulan penelitian dan implikasi penelitian yang telah diuraikan, maka dapat dikemukakan saran-saran sebagai berikut:

1. Siswa, khususnya siswa yang berada pada kategori sangat siap, siap, kurang siap bahkan siswa yang berada pada tidak siap, hendaknya berusaha untuk memperbaiki serta meningkatkan persiapannya menghadapi ujian sehingga berada pada kategori siap dan baik seksangat siap, dengan cara berusaha mempersiapkan diri semaksimal mungkin, baik persiapan fisik, psikis maupun persiapan menguasai materi pelajaran.

2. Guru BK terus meningkatkan dan mengembangkan layanan bimbingan dan konseling dalam rangka mempersiapkan siswa menghadapi ujian nasional, seperti memberikan layanan informasi, layanan penguasaan konten dan layanan bimbingan kelompok yang terkait dengan persiapan menghadapi ujian nasional.

3. Kepala Sekolah agar lebih memperhatikan dan memberikan kebijakan kepada guru BK dan guru mata pelajaran dalam pelaksanaan program BK di sekolah terutama berkenaan dengan persiapan siswa menghadapi ujian nasional.

4. Bagi Bapak/Ibu dalam kegiatan Musyawarah Guru Bimbingan dan Konseling (MGBK), hendaknya dalam pertemuan membahas tentang pentingnya mempersiapkan siswa dalam menghadapi ujian nasional.

Peneliti selanjutnya; dapat dijadikan sebagai dasar penelitian lanjutan dengan memperluas variabel dan subjek penelitian serta penelitian pengembangan tentang model penyiapan siswa mengadapi ujian nasional sehingga siswa sukses dalam mengikuti ujian nasional dan mendapatkan nilai yang bagus.

\section{DAFTAR RUJUKAN}

Abu Ahmadi dan Widodo, S. (2003). Psikologi Belajar, Jakarta : PT Rineka Cipta. A. Muri Yusuf. (2005). Metodologi Penelitian. Padang : UNP Press

Hasbullah Thabrany. (1995). Rahasia Sukses Belajar. Jakarta: PT. Raja Grafindo Persada

Irawadiy. (2009). Pengertian Persiapan, (http://irawadiymailcom.blogspot.com, diakses 10 Desember 2012)

Kartini Kartono. (1985). Bimbingan Belajar di SMA dan Perguruan Tinggi. Jakarta: CV Rajawali.

M. Sobri Sutikno. (2007). Rahasia Sukses Belajar dan Mendidik Anak. Mataram: NTP Press.

Mungin Edi Wibowo. (2011). "Kondisi Psikologis Siswa Menghadapi Ujian Nasional".Makalah pada Seminar dan Workshop tentang peranan Guru Menyiapkan Siswa Menghadapi UN di Padang, tanggal 16 Januari 2009

Peraturan Pemerintah No.19 Tahun 2005 tentang Standar Nasional Pendidikan

Soegyarto Mangkuatmodjo. (1997). Pengantar Statistik. Jakarta: Rineka Cipta

Syaiful Bahri Djamarah. (2002). Rahasia Sukses Belajar. Jakarta: PT. Rineka Cipta.

Tarmizi. (2009). Kiat Sukses Menghadapi Ujian Nasional, (online), (http://tarmizi.wordpress.com, diakses 10 Desember 2012)

Thursan Hakim, (2002). Belajar Secara Efektif. Jakarta: Puspa Swara.

Winarno Surahmad. (2002). Pengantar Metode Penelitian. Bandung: Tarsito 